\title{
Follicular Development of Aged Rats Ovarian Injected Human Umbilical Cord Mesenchymal Stem Cells
}

\author{
Resti Rahma Dianti', Alif Iman Fitrianto', Adkhilni Utami', Wining Astini', Adisti \\ Dwijayanti², Frans Dhyanagiri Suyatna ${ }^{3}$, Kelvin Yaprianto ${ }^{4}$, Indra Bachtiar ${ }^{4}$, Aryani \\ Sismin Satyaningtijas ${ }^{1}$, Adi Winarto', Arief Boediono ${ }^{1^{*}}$
}

\author{
'Department of Anatomy, Physiology and Pharmacology, Faculty of Veterinary Medicine, IPB \\ University, Jl. Agatis Kampus IPB Dramaga, Bogor, Jawa Barat, Indonesia, 16680 \\ 2Department of Pharmacy, Faculty of Medicine, University of Indonesia, Jl. Salemba Raya No 6, \\ Jakarta, Indonesia, 10430 \\ ${ }^{3}$ Departement of Clinical Pharmacology and Therapeutic, Faculty of Medicine, University of \\ Indonesia, JI. Salemba Raya No 6, Jakarta, Indonesia, 10430 \\ 4Stem Cell and Cancer Institute, Jl. A Yani No2, Pulo Mas, Jakarta, Indonesia, 13210
}

*Correspondence: Arief Boediono (ab@apps.ipb.ac.id)

\begin{abstract}
Female reproductive system showing the fastest signs of aging. The ovarian aging characterized by a decrease in follicular development. Stem cells are undifferentiated cells and can form a variety of different cells as the foundation of tissues and organs. Previous studies reported that Bone Marrow Mesenchymal Stem Cells (BM-MSCs) transplantation can restore follicular development in damaged ovarian rats. This study aimed to analyze the number of follicular development in aged rats and to analyze the capability of human Umbilical Cord Mesenchymal Stem Cells (hUC-MSCs) to improving follicular development in aged rats. This study used 3 mature rats ( 4 months old), and 9 nine aged rats (22-24 months old), Spraque Dawley (SD) strain. They were divided into four groups. The first and the second group was mature rats and aged rats without injection. The third and the fourth group was aged rats injected hUC-MSCs dose $10^{6}$ cells $/ \mathrm{kgBW}$ and hUC-MSCs dose $10^{7}$ cells $/ \mathrm{kgBW}$. The injection carried out 4 times at 3-month intervals. The parameters observed were follicular development and homing image of hUC-MSCs in ovarian tissue. The results showed that the number of follicular developments in aged rats 22-24 months decreased significantly compared to mature rats 4 months old. Injection of hUC-MSCs at dose $10^{6}$ cells $/ \mathrm{kgBW}$ and $10^{7}$ cells $/ \mathrm{kgBW}$ did not increase follicular development in aged rats. hUC-MSCs did not found in ovarian tissue. It could be concluded that aged rats 22-24 months old no longer productive indicated from the number of follicular developments and corpus luteum decreased. The injection of hUC-MSCs intravenously did not indicate an improvement of follicular development in aged rats 22-24 months old.
\end{abstract}

Key words: aging, follicles, homing, ovarian, stem cells

Copyright $\odot 2020$ JRVI. All rights reserved.

\section{Introduction}

Aging is a process that occurs naturally in organisms that associated with a decrease body function (Niccoli and Partridge 2012). In female, the reproductive system showing the 
fastest signs of aging. Ovarian aging is thought to be dominated by a gradual decreasing numbers of follicles, with diminished quality of oocytes (Li et al 2012). The follicles are the major endocrine and reproductive units of the ovary whose numbers determine both reproductive potential and reproductive life span (McGee and Hsueh 2000). Many agerelated diseases, such as cardiovascular disease, osteoporosis, Alzheimer's disease, cancer, and obesity occur related to the ovarian aging ( $\mathrm{Li}$ et al 2012).

Stem cells are undifferentiated cells found in the life stages of embryos, fetuses, and adults (Vladislav et al. 2014), and can form a variety of different cells as the foundation of tissues and organs (Edessy et al. 2014). Stem cells are considered as a potential new therapeutic agent for the treatment of degenerative diseases. One source of stem cells that has very good potential is the human Umbilical Cord Mesenchymal Stem cells (hUC-MSCs). Mesenchymal stem cells (MSCs) from the umbilical cord (UC) have many advantages. First, hUC-MSCs as a biological waste and typically discarded, therefore presents no ethical concerns (Batsali et al. 2013). Second, hUC-MSCs cells have an increased proliferative capacity, evidenced by a higher frequency of colony forming-unit fibroblasts (CFU-F) and a shorter population doubling time than other cells (Conconi et al. 2011). Third, hUC-MSCs show an absence or low expression of major histocompatibility complex (MHC) class II and costimulatory molecules may be considered immunoprivileged cells (De Miguel et al. 2012). hUC-MSC can produce several growth factors that can prevent cell apoptosis and trigger cell proliferation (Xu et al. 2007).

This study as a pre-clinical study that uses aged rats as an animal model that have decreased reproductive function. Rat becomes a good model to describe reproductive aging, because they have a short life span with a short reproductive cycle. Xenotransplantation of hUCMSCs (interspecies transplantation), can restores damaged ovaries by chemotherapy (Zhu et al. 2015). Astini et al. (2018) also found that xenotransplantation of human Wharton's Jelly-Mesenchymal Stem Cells (hWJ-MSCs) can improve pancreatic function in aged rats. Research by Fitrianto et al. (2018) found that hWJ-MSCs can improve testicular function in aged rats. Based on these studies, this study aimed to analyze capability of hUC-MSCs to improving the ovarian of aged rats. The hUC-MSCs cells used in this study were obtained from Stem cells and Cancer Institute in Jakarta.

\section{Materials and Methods}

This study used 12 rats (Rattus norvegicus) Sprague-Dawley (SD) strain, 3 mature rats 4 months old and 9 aged rats 22-24 months old. They were divided into four groups, the first group was three mature rats 4 months old, the second group was three aged rats 22 24 months old, the third group was three aged rats 22-24 months old injected hUC-MSCs dose $1\left(10^{6}\right.$ cells $\left./ \mathrm{kgBW}\right)$, and the fourth group was three aged rats 22-24 months old injected with hUC-MSCs dose $2\left(10^{7}\right.$ cells/kgBW). All treatments in this study have received approval from the ethical commission of the Education Animal Hospital, IPB University (RSHP-IPB) with the numbers: 21-2016 ACUC. This study used an experimental method, and carried out in 15 months.

\section{Analysis of Follicular Development}

The ovarian were processed using the paraffin method. Paraffin blocks were cut in $5 \mu \mathrm{m}$ thickness. Staining used was Haematoxylin and Eosin (HE) to observe follicular development. The analysis of follicular development based on histological image, which were divided into three categories, primordial, preantral, antral, and corpus luteum (CL). Primordial follicles have one layer of squamose granulosa cells. Preantral follicles have one 
or more layers of cuboid granulosa cells. The antral follicle has one or more layers of cuboid granulosa cells and antrum. Stages of follicular development are classified as in Figure 1. Number of follicular developments of each category were calculated per unit area of view.
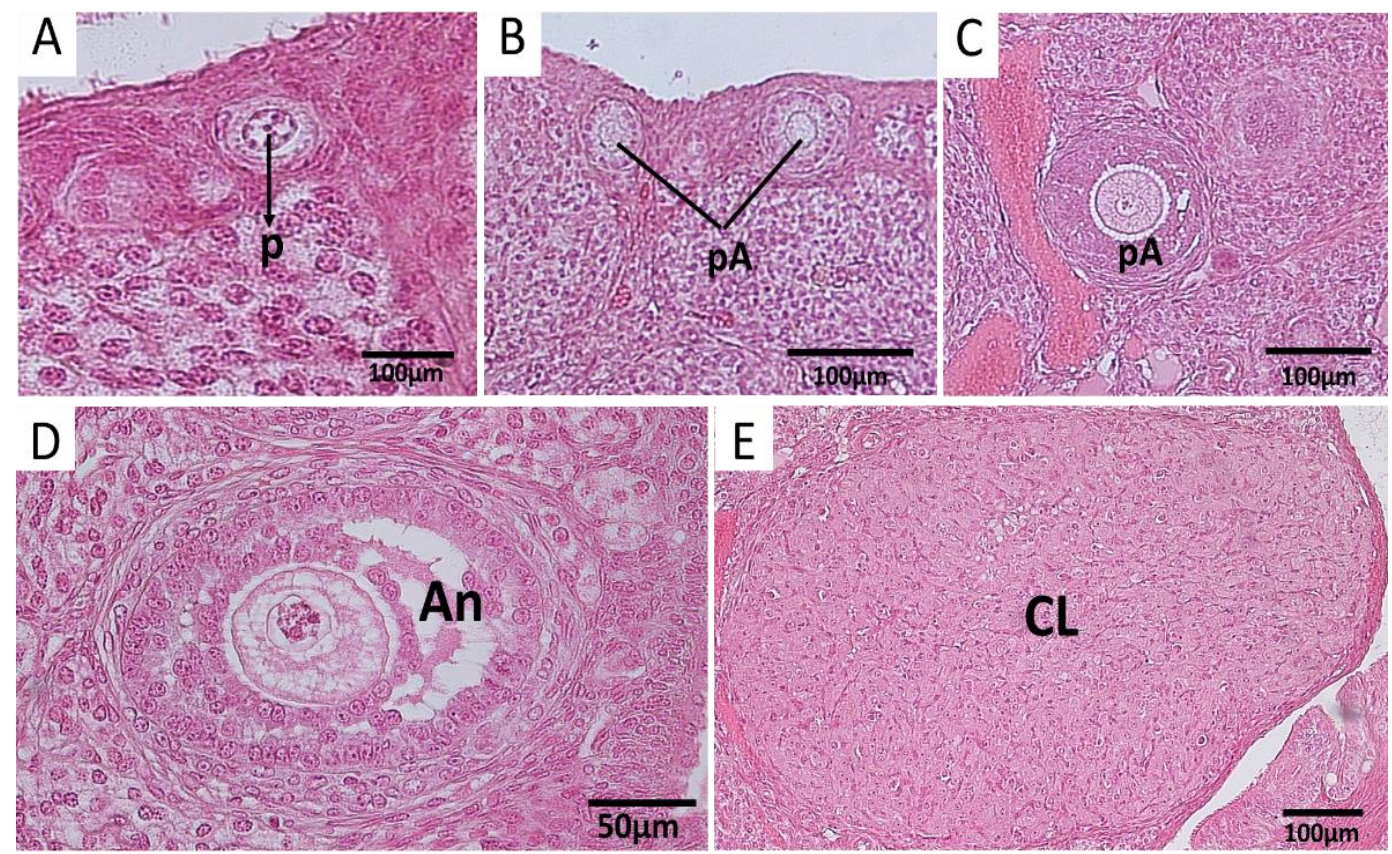

Figure 1. Classification of follicular development A) Primortdial, has one layer of squamous granulosa cells; B) and C) Preantral, has one or more cuboidal granulosa cell layers without antrum; D) Antral, has one or more cuboidal granulosa cell layers with antrum, E) Corpus luteum

\section{Homing Detection of $h$ WJ-MSCS}

Detection of hUC-MSCs homing was conducted to detect the presence of human mitochondria in the ovarian. This method is carried out used immunohistochemical staining method with anti-mitochondrial antibodies ab92824, which specifically only reacts with human mitochondria, and does not react with rat mitochondria. These antibodies will specifically mark the mitochondria of human cells in the ovarian tissue of rats injected with hUC-MSCs.

\section{Data analysis}

SPSS 16.0 software (SPSS Inc, Chicago, IL, USA) was used for data analysis, and data were report as the mean $\pm S D$. The normality of follicular development analyzed by SpahiroWilk. The difference in the number of primordial, preantral, and antral follicles in all groups analyzed by Kruskal Wallis, and then analyzed by $U$ Mann-Whitney to found out where the differences between groups. The difference in number of corpus luteum analyzed by ANOVA and Duncan to found out where the differences between groups.

\section{Results and Discussion}

\section{Analysis of Follicular Development}

Decreased ovarian function can be seen from a decrease in the number of follicular developments and corpus luteum in aged rats 22-24 months old. Calculation the number of follicular developments was done to see the difference in the number of follicular 
developments in each group. The number of follicular developments and corpus lutem presented in Table 1. Data in Table 1 shows the number of each follicle type per unit of view.

Table 1. Follicular Development and Corpus Luteum In All Group

\begin{tabular}{lcccc}
\hline \multirow{2}{*}{ Group } & \multicolumn{3}{c}{ Follicular Development \pm SD } & Corpus Luteum \\
\cline { 2 - 4 } & Primordial & Preantral & Antral & \pm SD \\
\hline 1 (mature rats) & $11.67 \pm 4.93^{\mathrm{a}}$ & $7.67 \pm 3.78^{\mathrm{a}}$ & $14.33 \pm 4.93^{\mathrm{a}}$ & $10.00 \pm 1.00^{\mathrm{a}}$ \\
2 (aged rats) & $0.33 \pm 0.57^{\mathrm{b}}$ & $1.00 \pm 1.00^{\mathrm{b}}$ & $3.33 \pm 0.57^{\mathrm{b}}$ & $4.67 \pm 4.51^{\mathrm{b}}$ \\
$3\left(10^{6}\right.$ cells $\left./ \mathrm{kgBW}\right)$ & $1.00 \pm 1.73^{\mathrm{b}}$ & $0.33 \pm 0.57^{\mathrm{b}}$ & $2.33 \pm 1.52^{\mathrm{b}}$ & $1.67 \pm 2.08^{\mathrm{b}}$ \\
$4\left(10^{7}\right.$ cells $\left./ \mathrm{kgBW}\right)$ & $0.33 \pm 0.57^{\mathrm{b}}$ & $0.67 \pm 1.15^{\mathrm{b}}$ & $6.00 \pm 2.00^{\mathrm{b}}$ & $2.00 \pm 1.00^{\mathrm{b}}$ \\
\hline \multicolumn{2}{c}{$\mathrm{a}, \mathrm{b}$ Different superscripts in the same column show significant differences $(\mathrm{p}<0.05)$}
\end{tabular}

Table 1 shows a significant difference in the number of primordial follicles in group 2 compared to group 1. This occurs because the rats in group 1 were mature rats 4 months old that still in the active reproductive period. Significant decrease in the number of primordial follicles in group 2 was caused because aged rats in group 2 were rats 22-24 months old, which the oocyte reserves in the ovaries are close to zero. This result same like Banerjee et al. said (2014) that ovarian aging is associated with a decrease in the number of primordial follicles.

Histomorphology of ovarian tissue in group 1 found many follicles at various development stages, like primordial follicles, preantral follicles, and antral follicles. While the Histomorphology of ovarian tissue in group 2 are found more less follicular antral development. This is same like by Broekmans et al. said (2009) that ovarian aging has a relationship with the number of antral follicles or antral follicle count (AFC). Histomorphology of ovarian tissue in mature and aged rats can be seen in Figure 2.
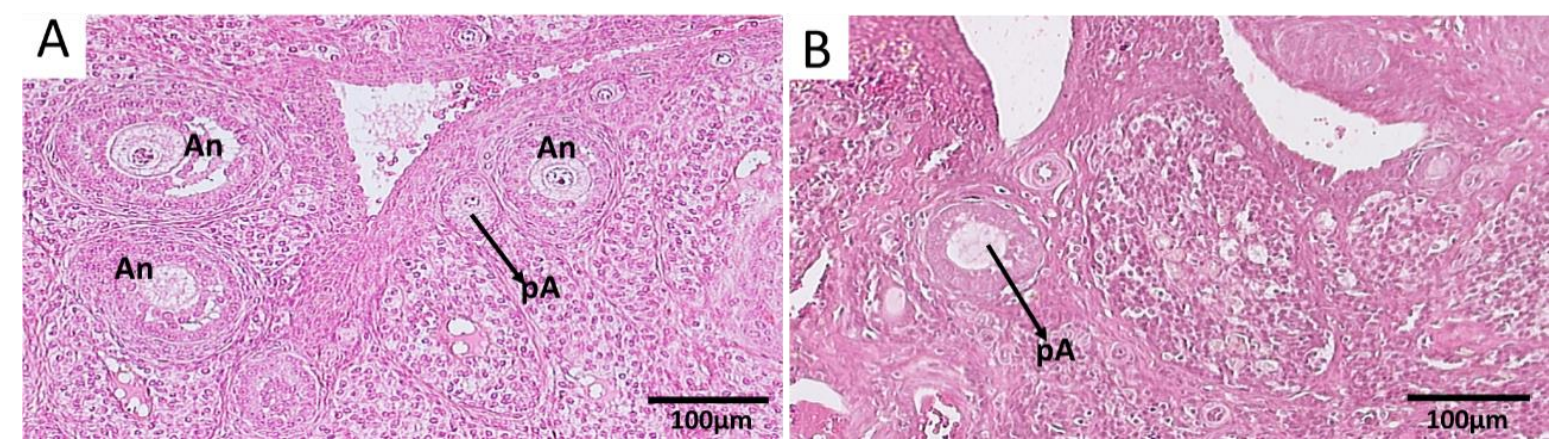

Figure 2. Follicular development found of matured and aged rats, A) Mature rats, shows many antral follicles (An) and preantral follicles (pA), B) Aged rats, shows few antral follicles and preantral follicles (pA)

Figure 2 shows that in group 1, mature rats 4 months old, many follicles to develop found, whereas in group 2, aged rats 22-24 months old, there were few developing follicles. Increased apoptosis results a decrease in the number of FSH receptors, and follicular development is highly dependent on the FSH hormone.

Table 4 shows the number of preantral and antral follicles in group 2 decreased significantly compared to group 1. This indicates that in aged rats 22-24 months old there has been a decrease in the number of follicular developments. This is supported by the statement of Acuna et al. (2009) who said that aged rats had decreased numbers of developing follicles. As ovaries getting older, the incidence of apoptosis increases in the ovaries. This is according 
to Adhikari and Liu (2009) due to changes in gene expression that causes a decrease in antiapoptosis in aged primodial follicles. This gives a great influence on follicular development, so the number of follicular developments in group 2 seems to have decreased significantly. Apoptosis that occurs in granulosa cells and theca cells that surround the oocytes can inhibit the follicular development and oocyte growth in. The growth and development of oocytes is highly dependent on two-way communication between oocytes and granulosa cells and theca cells (Gilchrist et al. 2004). Govindaraj et al. (2015) also said that in aging ovaries there were some changes in gene expression, such as Bracl, Rad51, Ercc2 H2ax, GRP78, FIGNL1, Calreticulin, BOK, and Peroxiredoxin 2 and 3, which have roles in DNA repair and anti-apoptosis.

The number of corpus luteum in group 2 was also seen to be decreased when compared to group 1. This indicates that aged rats 22-24 months old did not ovulate so there was no corpus luteum formed. Decreased corpus luteum also indicates the number of follicles undergoing atresia, so many follicles do not reach ovulation. Atresia is common in developing follicles but fails to reach the ovulation stage (Banerjee et al. 2014). The follicular development in the ovarian is strongly influenced by the hormone FSH and its receptors in granulosa cells (Freeman 1988). But in aged rats, granulosa cells that support the development of follicles undergo apoptosis, and causes FSH receptors to decrease (Freeman 1988). This causes oocyte atresia and fails to ovulate in aged rats. The reduced number of corpus luteum is also a sign that aged rats 22-24 months old have entered the phase of persistent diestrus. This is the same as expressed by Westwood (2008) that rats aged \pm 19 months have entered a period of persistent diestrus with a characteristic decrease in the level of the hormone progesterone due to a decreased corpus luteum.

Table 4 shows that the number of primordial follicles in rats in groups 3 and 4 did not have a significant difference with rats in group 2 . This was because rats in groups 2,3 , and 4 were aged rats 22-24 months old. The number of primordial follicles found in groups 2, 3, and 4 , shows that oocyte reserves in aged rats 22-24 months old are almost close to zero. These results show that injection of hUC-MSCs cannot increase the number of primordial follicles in rats aged 22- 24 months. That is because the number of primordial follicles cannot increase. Mammals have a limited number of oocytes and cannot be renewed. This is supported by Garg and Sinclair (2015) who say that mammals have a limited number of oocytes and cannot be renewed. This is evidenced by the absence of mitosis activity after birth.

The number of preantral follicles and antral follicles in groups 3 and 4 also did not differ significantly from group 2 . This showed that injection of hUC-MSCs could not increase the number of follicular developments in aged rats 22-24 months old. This can occur due to various factors. The first factor can be caused by a dose that is still not enough to trigger the process of follicular development in aged rats 22-24 months. The second factor can be caused because the animals in this experiment are physiological aged rats. Injection of hUCMSCs is done intravenously which means it will circulate systemically throughout the body. This can lead to the possibility of hUC-MSCs cells going to other organs and triggering repairs in these organs. This is supported by previous research conducted by Astini et al. (2018) who found that intravenous injection of hWJ-MSCs can improve pancreatic function in female and male rats aged 22-24 months. Research Fitrianto et al. (2018) also found that intravenous injection of hWJ-MSCs can improve testicular function in male rats aged 2224 months. The third factor can occur because the oocyte reserves that are almost close to zero makes no more follicular development that occurs in the ovarian. 
The number of corpus luteum in groups 3 and 4 also did not differ significantly from group 2. This indicates the injection of hUC-MSCs did not increase the number of ovulations in aged rats 22-24 months old. This can be caused by the number of follicular developments that does not increase in aged rats in groups 3 and 4, so ovulation does not occur. Ovulation that does not occur causes no corpus luteum formation.

\section{Homing Detection of $h W J-M S C S$}

Detection of hUC-MSCs homing cells was carried out by immunohistochemical procedures using anti-human mitochondria antibodies to examine hUC-MSCs cells that may be distributed into the ovaries. HUC-MSCs cells that homing into ovarian tissue will show positive immunoreactivity (brown in color) if there are human mitochondria in ovarian tissue. The results show there is no positive immunoreactivity in ovarian tissue in group 3 and 4. This indicates that there is no homing of hUC-MSCs in ovarian tissue. It can be concluded that hUC-MSCs that are injected intravenously do not develop and differentiate in ovarian tissue. Previous research also found something similar, Sensebé and FleuryCappellesso (2013) found that stem cells do homing almost to all organs but were not found in the ovaries and testes. This situation confirms that hUC-MSCs do not improving the follicular development. Immunohistochemical staining of ovarian tissue can be seen in Figure 3.
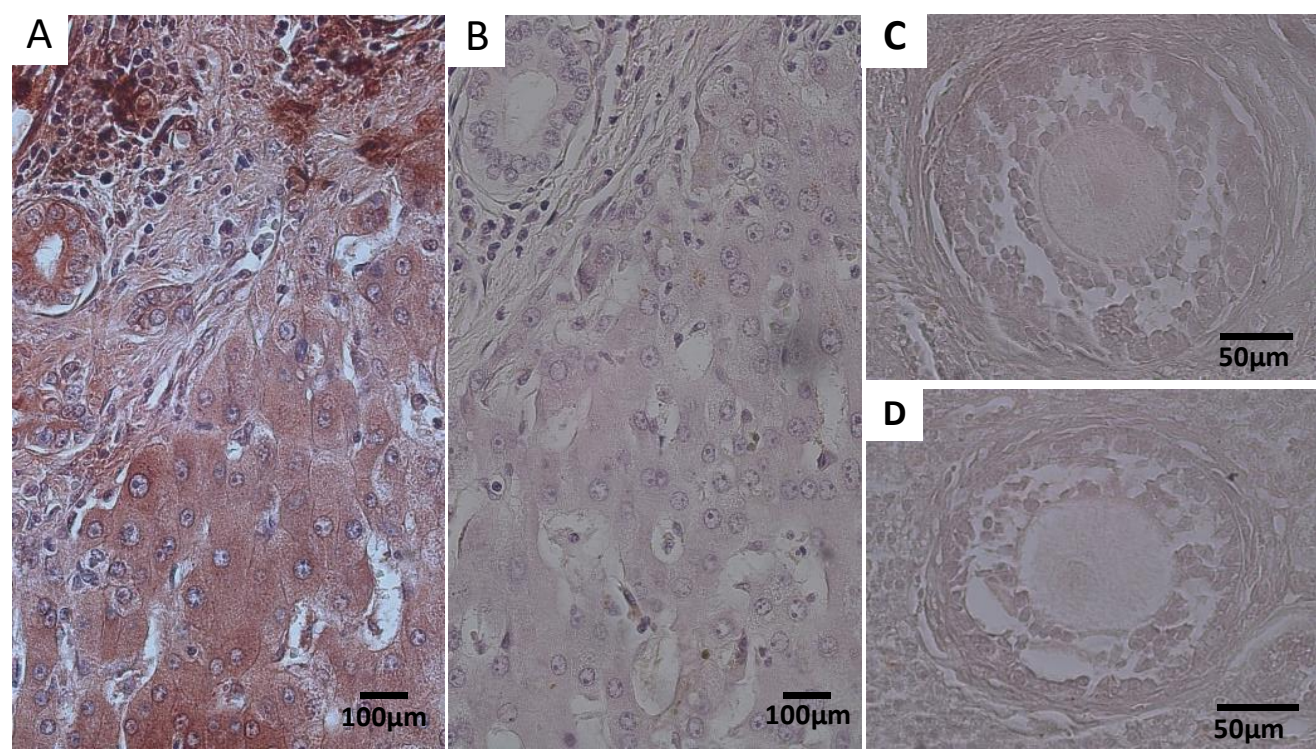

Figure 3 Immunohistochemistry in A) positive liver human tissue, B) negative liver human tissue, C) The third group, D) The fourth group

MSCs has several mechanisms to repair the tissue. First mechanism is MSCs cells enter the tissue and replace the damaged cells. Based on homing image results in this study, there are no human cells that are differentiated into cells in ovarian tissue. Another mechanism is that MSCs can produce growth factors, such as IGF-1, HGF, and VEGF, which can make improvements by preventing cell apoptosis and trigger the proliferation cells (Fu et al. 2008). There is no improvement in ovarian tissue of aged rats 22-24 months old can occur maybe because the dose of hUC-MSCs are still not enough to improve follicular development in aged rats 22-24 months old. 


\section{Conclusion}

Ovarian function of aged rats 22-24 months old has decreased as seen from the number of follicular developments and corpus luteum. Rats 22-24 months old can be used as a model in aging research. Injection hUC-MSCs dose $10^{6}$ cells $/ \mathrm{kgBW}$ and $10^{7}$ cells $/ \mathrm{kgBW}$ intravenously does not show potential to improving the number of follicular development of aged rats 22-24 months old. The author states there is no conflict of interest with the parties concerned in this research.

\section{Acknowledgment}

This research was supported by Stem Cells and Cancer Institute, Jakarta.

\section{Refferences}

Birchard SJ dan Sherding RG. 2000. Saunders Manual of Small Animal Practice. 2 nd edition. Pennsylvania: W. B. Saunders Company. page. 913-957.

Carlton WW dan McGavin MD. 2001. Thomson's Special Veterinary Pathology. St. Louis: Mosby-Year Book, Inc. page 209-245.

Debruyn K, Paepe D, Daminet S, Combes A, Duchateau L, Peremans K, Saunders JH. 2013. Renal dimensions at ultrasonography in healthy Ragdoll cats with normal kidney morphology: correlation with age, gender and bodyweight. Journal of Feline Medicine and Surgery 15 (12): 1046-1051

Idexx Laboratories. 2014. Urine Collection Methods. https://www.idexx.com/files/urinecollection-methods-en.pdf

Loesnihari, R. 2012. Peran analisa urin pada penanganan penyakit ginjal dan traktus urinarius. Majalah Kedokteran Nusantara, Vol. 45, No.3 Desember 2012, Hal :167176

Maryani, 2009. Kasus Urolithiasis Pada Anjing dan Kucing . Fakultas Kedokteran Hewan Institut Pertanian Bogor. Bogor.

Plumb, D. C. 2000. Veterinary Drug Handbook Eighth Edition. Wiley Blackwell, New Jersey.

National Institute of Health. 2011. Association of estimated glomerular filtration rate and albuminuria with mortality and end-stage renal disease: a collaborative meta-analysis of kidney disease cohorts. Kidney Int. 2011 June;79(12):1331-40.

Setiawan, Anjar Adi. 2015. Nefritis Pada Anjing English Bulldog. Universitas Brawijaya: Malang.

Wijayanti, T. 2008. Diagnosa Ultrasonografi Untuk Mendeteksi Kelainan Pada Organ Urinaria Kucing (Felis catus). SKripsi. Fakultas Kedokteran Hewan, Institut Pertanian Bogor. Bogor

Suartha, I. N. 2010. Terapi Cairan pada Anjing dan Kucing. Buletin Veteriner Udayana 2 (2) : 69-83. 